Wimalaratne, P.L.I., Kulathunga, U. and Gajendran, T., 2021. Comparison between the terms constructability and buildability: A systematic literature review. In: Sandanayake, Y.G., Gunatilake, S. and Waidyasekara, K.G.A.S. (eds). Proceedings of the $9^{\text {th }}$ World Construction Symposium, 9-10 July 2021, Sri Lanka. [Online]. pp. 196-207. DOI: https://doi.org/10.31705/WCS.2021.17. Available from: https://ciobwcs.com/papers/

\title{
COMPARISON BETWEEN THE TERMS CONSTRUCTABILITY AND BUILDABILITY: A SYSTEMATIC LITERATURE REVIEW
}

\author{
P.L.I. Wimalaratne ${ }^{1}$, U. Kulathunga ${ }^{2}$ and T. Gajendran ${ }^{3}$
}

\begin{abstract}
Buildability deals with the optimal integration of construction expertise at various project stages to achieve the overall project goals. Incorporation of buildability improves the construction project performance in terms of its cost, quality, productivity, safety, and results early completion. Thus, having a sound understanding of buildability concept is paramount for finding solutions for transforming current practices towards successful project deliveries. The numerous past studies reviewing the concept of buildability in the past have highlighted the interchangeability of the terms "constructability" and "buildability". However, in some studies, these two terms contradict rather than considered similar. Moreover, the application of the concept of buildability is widely discussed during the design phase while some studies recommend it to be applied in the construction phase. Thus, there is no clear consensus on the clarity of the key constructs of these terms or when to apply buildability. This paper aims to systematically review the application of the concepts "buildability" and "constructability" in the construction sector and compare the definitions to understand the key constructs and best phase of the construction project for its applicability. A structured literature review covering indexed publications from 2011-2021 was carried out to identify the existing literature. Following a Systematic Literature Review (SLR) technique, a total of 38 out of 162 research contributions have been considered for an in-depth analysis. The choice of interpretations, comments, statements, perspectives, and definitions used in 38 studies were examined. The study identified the key constructs of two terms and recommends applying buildability throughout the lifecycle of the project.
\end{abstract}

Keywords: Buildability; Constructability; Construction; Systematic literature review.

\section{INTRODUCTION}

The construction sector plays an important role in the socio-economic development of a country. Thus, the construction industry is undeniably essential to the growth of a nation and a key sector in the nation's economy (Ibrahim et al., 2010). A construction project is commonly acknowledged as a successful project when the aim of the project is achieved in terms of predetermined objectives of completing the project on time, within budget, and to the required quality standard (Kesavan et al., 2015). To achieve this goal, construction companies should complete the projects within their anticipated budgets and

\footnotetext{
${ }^{1}$ Department of Building Economics, University of Moratuwa, Sri Lanka, indraniw@uom.lk

${ }^{2}$ Department of Building Economics, University of Moratuwa, Sri Lanka, ukulatunga@uom.lk

${ }^{3}$ School of Architecture and Built Environment, University of Newcastle, Australia,

thayaparan.gajendran@newcastle.edu.au
} 
durations, and expected quality targets (Polat et al., 2014). However, in most construction projects severe time and cost overruns occur due to various factors (Arditi et al., 2017; Habibi and Kermanshachi, 2018; Ogbu and Adindu, 2019). Poor quality in construction projects has also become a common phenomenon in the world (Eriksson et al., 2019; Buba et al., 2020). The root causes of these issues have been identified as overbudgeting, lack of effective communication, lack of design integration, poor constructability, disregarding buildability (Rosayuru et al., 2018; Farrell and Sunindijo, 2020; Johnson and Babu, 2020; Kwofie et al., 2020b, 2020a). Among these causes, buildability has been identified as one of the main factors (Ansyorie, 2019; Al Khatib et al., 2020; Al-Fadhli, 2020). This is because buildability improves conceptual planning, procurement processes, construction methods, and involving stakeholders in the decision-making to achieve their satisfaction (Al-Fadhli, 2020).

Buildability is a concept deals with the optimal integration of construction expertise at various project stages to achieve the overall project goals (Naoum and Egbu, 2016). Leader et al. (2004), stated that buildability and its further improvement, could contribute to early completion of projects, a saving in project costs and costs of change orders (variations), enhance quality, improve safety performance, and achieve a high level of productivity rate. Some researchers stated that constructability and buildability are two identical concepts, except that buildability is typically used in the UK while constructability is usually used in the USA (Kalsaas et al., 2018; Finnie et al., 2018, 2019; Ansyorie, 2019; Ding et al., 2019). Whereas some researchers contradicted these two terms rather than considered similar (Capone et al., 2014; Contrada et al., 2019; Ding et al., 2019). Further, Kazaz et al. (2017) stated that "constructability" is best applied during the design stage. However, some studies stated that buildability is applicable throughout the entire project life cycle (Zolfagharian et al., 2012; Al-Fadhli, 2020; Samimpey and Saghatforoush, 2020). Accordingly, despite the significant value addition these concepts make to the outcome, there is still no consensus on clarity of the key constructs of these concepts or in which project stage the improvement measures should be implemented.

As described above, many studies show that research on this topic is fragmented, and not been coordinated. Thus, it is worth exploring the perceptions under these two terms to understand and compare the terms "buildability" and "constructability" and thereby derive the key constructs. This study systematically reviews the literature on "buildability" and "constructability" to understand how these terms have been interpreted and to provide clarity on which phase of the construction project is the best suit to apply buildability concept. Therefore, this paper aims to systematically review the application of the concept "buildability" and "constructability" in the construction sector.

Accordingly, the paper is structured as follows. First, the research methodology adopted for the study is presented. This is followed by the results and discussion of the findings. A table is presented within the results, reflecting the SLR findings in a form of a tabulated summary. Finally, the conclusion is presented summarising the key findings of the study.

\section{METHODOLOGY}

\subsection{The Process of Systematic Review}

SLR technique was used to carry out the literature search as this is widely practiced as a system-driven way of collecting unbiased literature. Biolchini et al. (2005) defined a 
systematic review as "specific methodology of research, developed to gather and evaluate the available evidence pertaining to a focused topic". A systematic review must firstly aim for comprehensive treatment of a particular topic through a search of an appropriate electronic database. Applying an appropriate analysis method to identify key concepts in the research question, develop appropriate search terms to describe these, and determine inclusion and exclusion criteria is essential when making the final selection of articles. The following keywords are considered for the question of this research (refer Table 1).

Table 1: Keywords for the SLR

\begin{tabular}{rc}
\hline Population & Intervention \\
\hline "Construction*" & "Constructability" OR "Buildability" \\
\hline
\end{tabular}

Rather than selecting random studies for systematic reviews, PRISMA method was adopted to improve the quality of review as it follows a four-phased flow diagram. There should be a sound research question supported by a precise aim and objectives in order to develop the search strategy, the eligibility criteria, and the study selection which are very important components of the PRISMA checklist (Eriksen and Frandsen, 2018).

\subsection{SEARCh STRATEGy/INITIAL RESUltS}

The systematic review is based on indexed publications. The database considered was Scopus Document Search, which consists of multidisciplinary publications. Following the identification procedure, 136 records were identified through a database search. Additional 26 records were identified through other sources. Only the records that were explicitly related to the research question were selected through other sources. To avoid losing the relevant important articles while conducting the initial search, the terms "Definition", "Characteristics" and "Explanation" were eliminated from the string. Accordingly, "Constructability" OR "Buildability" AND "Construction*" was the search string used.

A systematic review must provide a clearly defined boundary such that only studies relevant to the topic are included. This research included only full-length peer-reviewed articles in the "construction" context. The articles were selected if the terms "constructability" or "buildability" was detailed in the title, abstract, keywords, or within the text in the articles. As a result, 162 studies were identified for review.

\subsection{EligibILITy CRITERIA}

It is necessary to have eligibility criteria for the selection which need to be appraised for the validity, applicability, and comprehensiveness of a review (Moher et al., 2015). These eligibility criteria identify the inclusion and exclusion conditions for the study. Table 2 presents the eligibility criteria for this study.

Table 2: Eligibility criteria

\begin{tabular}{lll}
\hline \multicolumn{1}{c}{ Inclusion Criteria } & \multicolumn{1}{c}{ Exclusion Criteria } & \multicolumn{1}{c}{ Rationale } \\
\hline Sources published in & Sources published other than & $\begin{array}{l}\text { English is the international and } \\
\text { the universal language. }\end{array}$ \\
English language & in English & Avoiding out of date results \\
Publication year from & $\begin{array}{l}\text { Publication year prior to } \\
2011-2021\end{array}$ & 2011
\end{tabular}




\begin{tabular}{lll}
\hline \multicolumn{1}{c}{ Inclusion Criteria } & \multicolumn{1}{c}{ Exclusion Criteria } & \multicolumn{1}{c}{ Rationale } \\
\hline Published sources & $\begin{array}{l}\text { unpublished sources and } \\
\text { studies under review }\end{array}$ & $\begin{array}{l}\text { Unpublished articles and under } \\
\text { review articles were not } \\
\text { included } \\
\text { Research areas related to } \\
\text { construction and built } \\
\text { environment }\end{array}$ \\
$\begin{array}{l}\text { Research areas: Social } \\
\text { Sciences, and Engineering }\end{array}$ & $\begin{array}{l}\text { Research areas: Computer } \\
\text { Science, Medicine, Business } \\
\text { Management and } \\
\text { Accounting, Economics and }\end{array}$ & \\
& Finance, etc. & \\
$\begin{array}{l}\text { Document type: Articles, } \\
\text { Conference Papers, Book }\end{array}$ & \multicolumn{1}{c}{-} & - \\
$\begin{array}{l}\text { Chapters, Books } \\
\text { Terms "Buildability" and } \\
\text { "constructability" in } \\
\text { topic, abstract, and body }\end{array}$ & & \\
\hline
\end{tabular}

The number of full-text articles reviewed for eligibility is similar to the difference between the screened records and the exclude records (162-124=38). 38 articles were considered eligible for full-text review. During the full-text review, 18 articles were found applicable to the research question. The reasons for excluding the articles after the fulltext review were recorded.

\subsection{StUdy SELECTION AND DATA EXTRACTION}

The selection of the articles is depicted in the flow diagram shown in Figure 1.

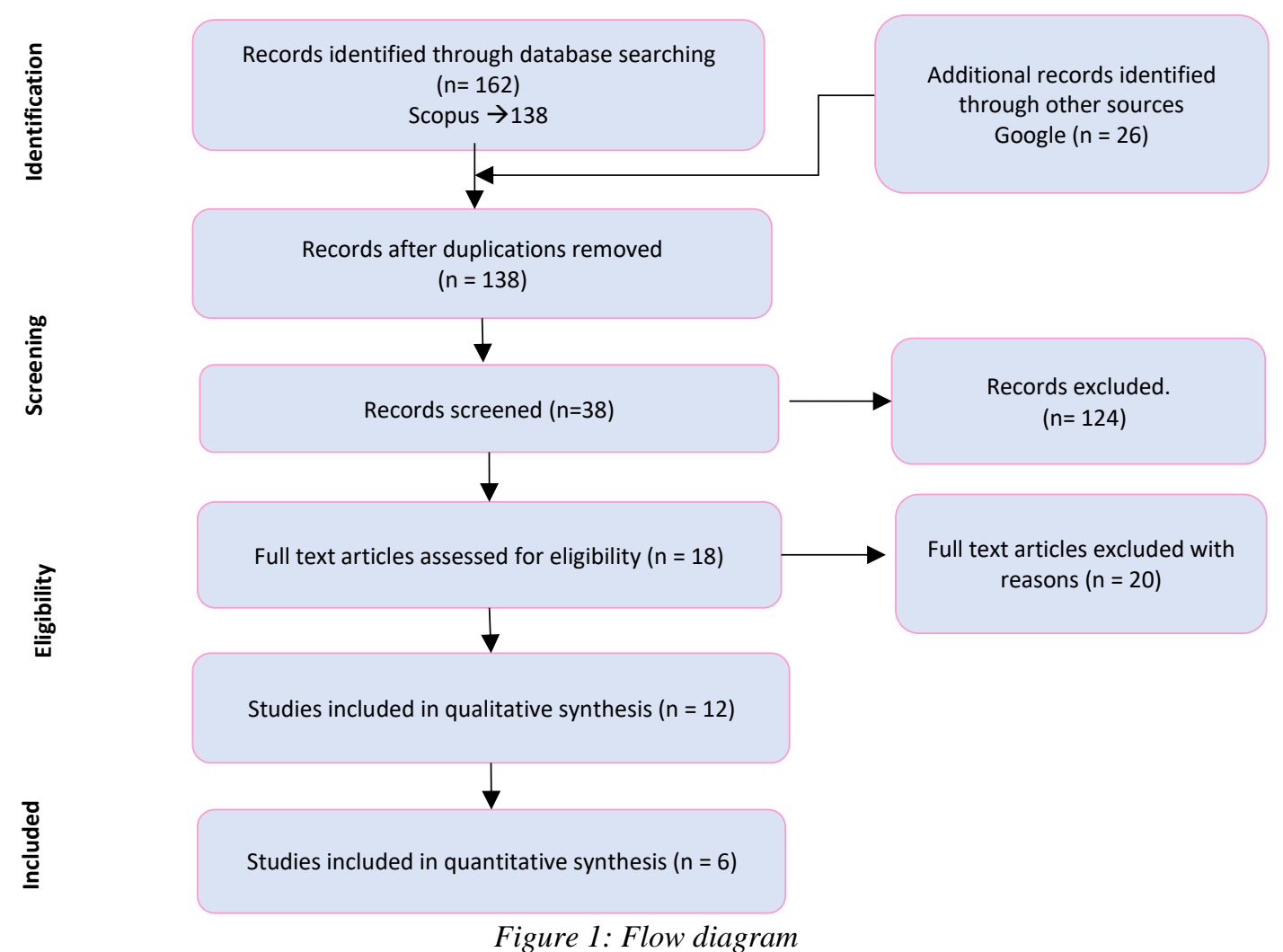


To avoid reviewing the same article from different databases, the duplications were removed. The title, abstract, keywords, authors' names, journal name, and year of publication, access type, and source name of the identified records were exported to an Excel spreadsheet. All the identified articles were subjected to title and abstract screening initially and categorized as: relevant, irrelevant, and unsure by a single reviewer. In this stage, (1) articles not relating to keywords, (2) articles not contributing to the definition of buildability or constructability, and (3) articles that were completely irrelevant to the research area were excluded. Upon the title and abstract screening, the final set of articles was concluded for the second screening. In the second screening process, the full text of all the relevant articles were reviewed and the necessary data was extracted. In this study, mainly the extracted items used were the definitions, statements, comments, and perspectives of constructability and buildability. Geographic location of the study, methodology, and whether the authors focused on both constructability and buildability, which phase of the construction project was applicable, and the year of publication were also considered to derive conclusions and recommendations.

\section{RESULTS}

\subsection{DEFINITIONS}

Following the analysis of 18 articles, 15 definitions were found (refer Table 3). Furthermore, additional statements defining the terms "constructability" and "buildability" found in the studies were categorized into several definitional attributes of buildability.

Several studies pointed out that the terms "constructability" and "buildability" are two different terms used interchangeably in different parts of the world (Kalsaas et al., 2018; Finnie et al., 2018, 2019; Ansyorie, 2019; Ding et al., 2019). Generally, "constructability" is more frequently used in Indonesia, France, Turkey, Korea, Taiwan, South Africa, Iran, Norway, and Iraq. "Buildability" is mostly adopted by United States and Singapore although both the countries use both terms. Asia (includes Singapore, Indonesia, Korea, Taiwan, Iran, Malaysia, and Iraq) uses both terms interchangeably. Europe (France, Italy, and Norway) mostly use "constructability", but Italy and France use both terms interchangeably.

With regard to the definitions, there are two common definitions for constructability that have been cited in the referenced articles as shown in Table 3. The Construction Industry Institute (CII) in United States defined "constructability" as "the optimal use of construction knowledge and experience in planning, design, procurement, and field operations to achieve overall project objectives" (CII, 1986). And the Construction Industry Institute Australia (CIIA) defined "constructability" as "the integration of construction knowledge in the project delivery process and balancing the various project and environmental constraints to achieve project goals and building performance at an optimum level" (CIIA, 1996).

The most frequently cited definition within the selection criteria of the articles for buildability was defined by the Construction Industry Research and Information Association (CIRIA) in the UK as "the extent to which the design of a building facilitates ease of construction, subject to the overall requirements for the completed building" (CIRIA, 1983). 
Table 3: Data analysis

\begin{tabular}{ll}
\hline \multicolumn{1}{c}{ Reference } & \multicolumn{1}{c}{ Definition } \\
\hline (Aktas et al., 2012) & (CII, 1986) \\
(Zolfagharian et al., 2012) & (CII, 1986) \\
(Yustisia, 2014) & (CII, 1986) \\
(Capone et al., 2014) & $\begin{array}{l}\text { Constructability, which embraces the functions both of } \\
\text { project management and design, covering a wider scope } \\
\text { than Buildability. } \\
\text { (CII, 1986) }\end{array}$ \\
(Getuli et al., 2015) & $\begin{array}{l}\text { (CII, 2016) } \\
\text { "The interaction between design and construction phases in } \\
\text { construction project is defined by the term constructability }\end{array}$
\end{tabular}

(Lee et al., 2017) $\quad$ (CII, 1993)

Other Attributes - Interpretations / statements

Constructability is an abstract concept that enables successful

realization of building projects given that critical factors are correctly identified [Arditi's (2002), Lam's (2009), Saghatforoush's (2009) and Lam's (2012) studies as cited in Aktas et al. (2012)].

Constructability is not only limited to design stage but should be considered during whole project lifecycle.

To avoid accidents and various dangers in the construction process that could lead to loss of property, objects, and human lives the concept of constructability can be implemented to achieve the project objectives.

Constructability interacts with the project management techniques that utilize optimally knowledge and experiences on building effective, to improve the achievement of the project objectives.

improved design; better construction methods; more accomplished site management; more effective teamwork

"Constructability is an indicator of the design quality."

(Yang, et al. 's 2003 study cited in Kazaz et al. (2017))

Although review on constructability covers entire phase of a project, the term is mainly used to indicate understanding of the possibility of construction in phase prior to the construction.

The aim of the constructability is found the ways to improve and increase the cost efficiency of the construction project, improve the quality of the project, and this concept as a bridge between designer and construction companies

\section{(Govender et al., 2018) ～(CII, 1986), (CIIA,1996)}

(Kalsaas et al., 2018)

(Lee et al., 2018)

The definition of constructability varies slightly from country to country, but the common concept is to foster
Good constructability can be expected to yield lower costs and quicker production for the contractor, if they are otherwise operationally efficient and external risks are manageable.

to utilize constructability knowledge effectively, the right information at the proper time should be provided to the design team. The 


\section{Reference}

(Finnie et al., 2019)

(Ansyorie, 2019)

(Contrada et al., 2019)

(Ding et al., 2019)

(Al-Fadhli, 2020)

(Samimpey and

Saghatforoush, 2020)

(Jadidoleslami et al., 2021)

\section{Definition}

efficient decision-making by fully reflecting construction knowledge and experience from the early stages of the project.

(CII, 1986)

(CII, 1986)

Constructability is also defined as the extent to the design facilitate ease of construction [Bakti and Trigunarsyah's (2003) study cited in Ansyorie (2019)].

(CII, 1986)

(CIRIA, 1983)

Constructability is one of the project management methods to evaluate the whole construction process.

"an effective technique that implements a detailed review of design drawings, documents, specifications, and construction processes by highly experienced engineers, working with original team of the project before construction mobilization" [Douglas and Gransberg's (2009) study cited in Al-Fadhli (2020)].

(CII, 1986)

(CIIA, 1992)

Constructability is one of the techniques that connect the implementation and construction phases to the design and planning phases.

(CII 1986)
Other Attributes - Interpretations / statements

information should also have appropriate levels of detail to enable its successful integration with specific design activities.

Constructability (or buildability) is the ability to construct a building efficiently, economically and to agreed quality levels from its constituent materials, components and sub-assemblies.

Constructability enhances buildability which does not focus only on labor productivity, but it also aims to reach and guarantee building performance levels.

It is defined as a concept with relative, not absolute, value to increase optimization capacity of resources, such as workforce, time, cost, quality and working environment conditions [JadidAlEslami et al.'s (2018) study as cited in Ding et al. (2019)].

"the constructability focuses on optimizing the whole construction process. Effective constructability applications ideally begin at the conceptual and planning phase and continue to construction."

Constructability is a project management technique, which examines construction logic from beginning to end, in order to identify obstacles, restrictions, and potentials.

Constructability is one of the project management methods to evaluate the whole construction process. 
These definitions bring together the ability of the transformation of a design into construction as well as sufficient incorporation of such contractor's know-how as early as possible in the procurement process. On the other hand, there is a consensus that the design stage is critical for implementing buildability (Latham, 1994; Low, 2011; Ding et al., 2019). Adding to this, Contrada et al. (2019), Naoum and Egbu (2016), and Lam and Wong (2011) asserted that if a proactive contractor is involved at the pre-construction stage with advanced works, programme planning, and materials procurement, as well as the buildability of project design will be remarkably enhanced.

For example, Bakti et al. (2003) stated that "constructability or buildability is a project quality improvement technique that if implemented throughout the project delivery process, mitigates the challenges" whereas, Capone et al. (2014) stated that "constructability, which embraces the functions both of project management and design, covering a wider scope than the Buildability". Adding to this, Contrada et al. (2019) stated that "constructability" is a concept that enhance "buildability" extending the practice of sharing knowledge to the whole construction lifecycle. Accordingly, application of buildability has to be done throughout the life cycle of a construction project.

Based on the various definitions of constructability, the most frequently used keywords were "integration of construction knowledge", "optimum use of construction knowledge and experience", "optimization of the design and execution of a construction", "balancing the various project and environmental constraints", "reflecting construction knowledge and experience from the early stages of the project", "ease of construction", and "adoption of construction techniques and processes". For buildability, the frequently used keywords were "optimal integration of construction expertise and experience", "ease of construction", "design that facilitates building construction", "construct efficiently, economically and to agreed quality levels", "project quality improvement technique", and "design and detailing". Figure 2 shows the identified key constructs of the two terms as similarities and differences.

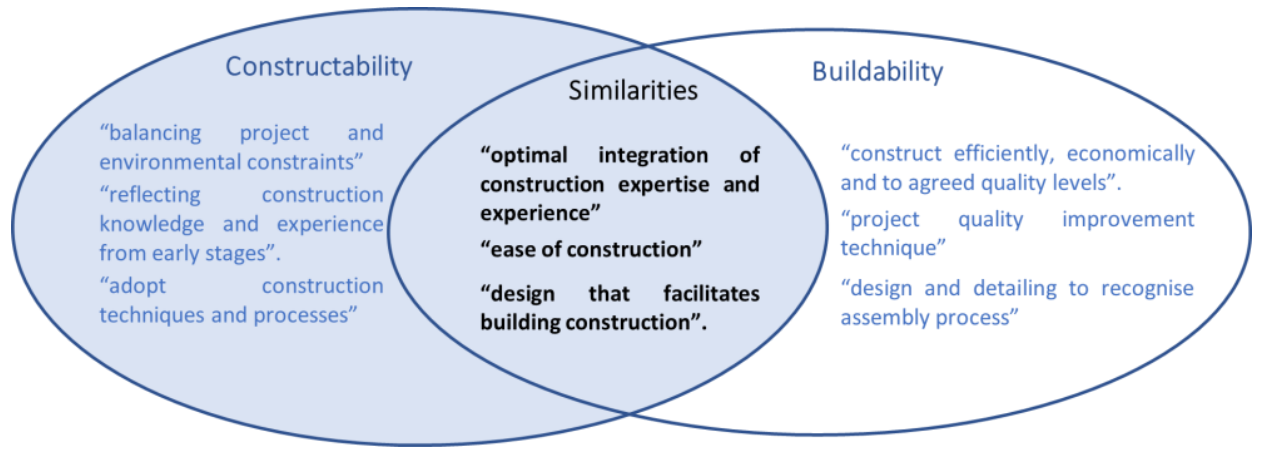

Figure 2: Similarities and differences identified in the key constructs.

\subsection{OTHER DEFINITIONAL ATTRIBUTES OF BUILDABILITY}

The definitional attributes that should be included in the terms "buildability" and "constructability" have been identified and categorized under (1) Interpretations/ Comments/ statements, and (2) Perspectives.

Two (02) studies interpreted constructability (or buildability) as a project management technique to review construction processes from start to finish during the pre-construction 
phase. There were two (02) studies out of the 18 that have considered BDAS (Buildable Design Appraisal System). Two (02) studies have confirmed that if buildability is considered during the design phase itself, will lead to enhanced safety performances. Four (04) studies out of the 18 selected studies have recommended using modern technology such as AR (augmented reality), 3D workspace modelling, BIM (Building Information Modelling) in the construction projects to improve buildability. 11 studies out of the 18 have recommended the application of buildability and constructability throughout all the phases of the construction projects whereas 8 studies recommend considering buildability and constructability during the design phase.

\section{CONCLUSIONS}

Constructability and buildability are two terms used in the literature to discuss the optimum use of construction knowledge and experience in the construction process. The purpose of this paper is to systematically review the terms "buildability" and "constructability" in the construction sector to compare and identify the similarities and differences in the key constructs. Thus, to provide useful insights to the stakeholders in identifying the key constructs that need to be incorporated to enhance the construction project performance. A structured literature review covering indexed publications from 2011 to 2021 was carried out to identify the existing literature. It is noted that the definitions of these terms have not significantly emerged over time.

Although constructability and buildability can be used interchangeably, differences between them could still be found. The researchers found that buildability concerns more on design whereas constructability covers the wider scope, and it embraces project management systems, safety performance, value engineering, and use of modern technology. This study also reveals that it is equally important to apply constructability or buildability throughout the entire life cycle of construction projects.

\section{REFERENCES}

Aktas, C.B., Ryan, K.C., Sweriduk, M.E. and Bilec, M.M., 2012. Critical success factors to limit constructability issues on a net-zero energy home. Journal of Green Building, 7(4), pp.100-115.

Al-Fadhli, S.K.I., 2020. Value engineering and constructability assessment relating infrastructure projects. In: IOP Conference Series: Materials Science and Engineering. Institute of Physics Publishing, pp. 111.

Anon., 2021. CIRIA Construction Industry Research and Information Association (1983) Buildability An Assessment. CIRIA, London. - References - Scientific Research Publishing [online]. Available from: https://www.scirp.org/(S(351jmbntvnsjt1aadkposzje))/reference/ReferencesPapers.aspx?ReferenceID $=1777692$ [Accessed 8 Apr 2021].

Ansyorie, M.M.A., 2019. Concepts of constructability for project construction in Indonesia. In: The $2^{\text {nd }}$ International Conference on Green Civil and Environmental Engineering. IOP Conference Series. Materials Science and Engineering, Malang, East Java, Indonesia 4-6 September 2019. IOP Publishing Ltd.

Arditi, D., Nayak, S. and Damci, A., 2017. Effect of organizational culture on delay in construction. International Journal of Project Management [Online], 35(2), pp. 136-147.

Bakti, E. and Trigunarsyah, B., 2003. Constructability implementation at corporate level. In: Proceedings of the $9^{\text {th }}$ East Asia-Pacific Conference on Structural Engineering and Construction (EASEC-9). Department of Civil Engineering, Institute Technology Bandung (ITB), pp. 88-93.

Biolchini, J., Gomes. M.P., Candida, C.N.A. and Horta T.G., 2005. Systematic Review in Software Engineering. Systems Engineering and Computer Science Department. COPPE/UFRJ. 
Buba, G.S.P., Hamid, R.A., Ramly, Z.M., Jatau, T.S. and Jatau, J.D., 2020. Unique Factors of Best Value Procurement from the Perspective of Nigerian Construction Professionals. International Journal of Built Environment and Sustainability, 7(2), pp. 1-14.

Construction Industry Institute Australia (CIIA), 1993. Constructability Principles File. University of South Australia, Adelaide, Australia. CIIA. RS34-2.

Construction Industry Institute Australia (CIIA), 1992. Constructability Principles File. University of South Australia, Adelaide, Australia. (CIIA). SD-83.

Construction Industry Institute Australia (CIIA), 1996. Constructability Principles File. Brisbane, Australia. CIIA.

Construction Industry Institute United States (CII), 1986 [Online]. Available from: https://www.construction-institute.org/resources/knowledgebase/bestpractices/constructability/topics/rt-003 [Accessed 12 Apr 2021].

Construction Industry Institute United States (CII)., 2016. CII [Online]. Available from: https://www.construction-institute.org/resources/knowledgebase/knowledge-areas/performanceassessment/topics/bm-vbp\#presentation325 [Accessed 12 Apr 2021].

Capone, P., Getuli, V. and Giusti, T., 2014. Constructability and safety performance based design: A design and assessment tool for the building process. In: $31^{\text {st }}$ International Symposium on Automation and Robotics in Construction and Mining, ISARC 2014 - Proceedings. University of Technology Sydney, pp.313-320.

Contrada, F., Kindinis, A., Caron, J.F., and Gobin, C., 2019. An early-design stage assessment method based on constructibility for building performance evaluation. In: IOP Conference Series: Materials Science and Engineering [online], 609(7), 072070. Available from: https://iopscience.iop.org/article/10.1088/1757-899X/609/7/072070 [Accessed 29 Mar 2021].

Ding, C.S., Salleh, H. and Kho, M.Y., 2019. Critical constructability principles for girder bridge construction in Malaysia. International Journal of Sustainable Construction Engineering and Technology, 10(2), pp. 41-51.

Eriksen, M.B. and Frandsen, T.F., 2018. The impact of PICO as a search strategy tool on literature search quality: A systematic review. Journal of the Medical Library Association, 106 (4), pp. 420-431.

Eriksson, P.E., Volker, L., Kadefors, A., Lingegard, S., Larsson, J. and Rosander, L., 2019. Collaborative procurement strategies for infrastructure projects: A multiple-case study. In: Proceedings of Institution of Civil Engineers: Management, Procurement and Law [online]. ICE Publishing, 197-205. Available from: https://www.icevirtuallibrary.com/doi/10.1680/jmapl.19.00016 [Accessed 31 Jan 2021].

Farrell, A. and Sunindijo, R.Y., 2020. Overcoming challenges of early contractor involvement in local government projects. International Journal of Construction Management [online], pp. 1-8. Available from: https://doi.org/10.1080/15623599.2020.1744216.

Finnie, D., Ali, N.A., and Park, K., 2018. Enhancing off-site manufacturing through early contractor involvement (ECI) in New Zealand. Proceedings of Institution of Civil Engineers: Management, Procurement and Law, 171(4), pp.176-185.

Finnie, D., Ali, N.A., and Park, K., 2019. Design development post contract signing in New Zealand: Client's or contractor's cost?. Proceedings of Institution of Civil Engineers: Management, Procurement and Law, 172(4), pp. 146-156.

Getuli, V., Giusti, T., and Capone, P., 2015. A decision support system (DSS) for constructability assessment in seismic retrofit of complex buildings. In: $32^{\text {nd }}$ International Symposium on Automation and Robotics in Construction and Mining: Connected to the Future, Proceedings. International Association for Automation and Robotics in Construction (I.A.A.R.C).

Govender, K., Nyagwachi, J., Smallwood, J.J., and Allen, C.J., 2018. The awareness of integrated project delivery and building information modelling - facilitating construction projects. International Journal of Sustainable Development and Planning, 13(1), pp. 121-129.

Habibi, M. and Kermanshachi, S., 2018. Phase-based analysis of key cost and schedule performance causes and preventive strategies: Research trends and implications. Engineering, Construction and 
Architectural Management [Online], 25(8), pp. 1009-1033.

Ibrahim, A.R. Bin, Roy, M.H., Ahmed, Z.U. and Imtiaz, G., 2010. Analyzing the dynamics of the global construction industry: past, present and future. Benchmarking: An International Journal, 17(2), pp. 232252.

Jadidoleslami, S., Saghatforoush, E. and Zare Ravasan, A., 2021. Constructability obstacles: An exploratory factor analysis approach. International Journal of Construction Management, 21(3), pp. 312-325.

Johnson, R.M. and Babu, R.I.I., 2020. Time and cost overruns in the UAE construction industry: A critical analysis. International Journal of Construction Management, 20(5), pp. 402-411.

Kalsaas, B.T., Hannås, G., Frislie, G. and Skaar, J., 2018. Transformation from design-bid-build to designbuild contracts in road construction. In: IGLC 2018 - Proceedings of the $26^{\text {th }}$ Annual Conference of the International Group for Lean Construction: Evolving Lean Construction Towards Mature Production Management Across Cultures and Frontiers. The International Group for Lean Construction, pp. 3445.

Kazaz, A., Acikara, T., Ulubeyli, S. and Koyun, H., 2017. Detection of architectural drawings errors in 3 dimension. Procedia Engineering, pp. 1018-1025.

Kesavan, M., Gobidan, N.N., and Dissanayake, P.B.G., 2015. Analysis of factors contributing civil engineering project delays in Sri Lanka. In: $6^{\text {th }}$ International Conference on Structural Engineering and Construction Management 2015. pp. 40-46.

Khatib, B. Al, Poh, Y.S., El-Shafie, A., Al Khatib, B., Poh, Y.S. and El-Shafie, A., 2020. delay factors management and ranking for reconstruction and rehabilitation projects based on the Relative Importance Index (RII). Sustainability, 12(15), p. 6171.

Kwofie, T.E., Aigbavboa, C. and Thwala, W., 2020a. Effective construction project delivery. Improving Communication Performance in Non-Traditional Procurement Systems. Springer.

Kwofie, T.E., Aigbavboa, C. and Thwala, W., 2020b. Critical factors for managing non-traditional procurement communication. In: Kwofie, T. E., Aigbavboa, C., and Thwala, W., eds. [Online]. Cham: Springer International Publishing, pp. 105-117. Available from: https://doi.org/10.1007/978-3-03049374-5_8.

Lam, P., Wong, F.W.H., Chan, A.P.C., Shea, W.C.Y. and Lau, J.W.S., 2012. A scheme design buildability assessment model for building projects. Construction Innovation: Information, Process, Management, 12(2), pp. 216-238.

Lam, P.T.I. and Wong, F.W.H., 2011. A comparative study of buildability perspectives between clients, consultants and contractors. Construction Innovation, 11(3), pp. 305-320.

Latham, M., 1994. Constructing the team. Department of Environment, UK.

Leader, P., Davis, P., Davis, P., Love, P., Baccarini, D., Affiliates, P. and Tookit, P.M., 2004. Report Building Procurement Methods, (June 2008).

Lee, J.W., Cho, K., Hwang, T., Han, J. yeon, and Kim, T., 2018. Process for integrating constructability into the design phase in high-rise concrete buildings: Focused on temporary work. International Journal of Concrete Structures and Materials, 12(1).

Lee, S.Y., Kwon, S.W., and Ko, T.K., 2017. AR(augmented reality) based 3D workspace modeling for quality assessment using as-built on-site condition in remodeling construction project. In: ISARC 2017 - Proceedings of the $34^{\text {th }}$ International Symposium on Automation and Robotics in Construction. International Association for Automation and Robotics in Construction I.A.A.R.C), pp. 181-188.

Liau, Y.H. and Lin, Y.C., 2017. Application of civil information modeling for constructability review for highway projects. In: ISARC 2017 - Proceedings of the $34^{\text {th }}$ International Symposium on Automation and Robotics in Construction. International Association for Automation and Robotics in Construction I.A.A.R.C), pp. 416-422.

Low, S.P., 2011. Building and sustainability controls in singapore: A journey in time. Procedia Engineering, 20, pp. 22-40. 
Moher, D., Shamseer, L., Clarke, M., Ghersi, D., Liberatî, A., Petticrew, M., Shekelle, P., Stewart, L.A., Group, P.P., Liberati, A., Petticrew, M., Shekelle, P., Stewart, L.A., Estarli, M., Barrera, E.S.A., Martínez-Rodríguez, R., Baladia, E., Agüero, S.D., Camacho, S., Buhring, K., Herrero-López, A., GilGonzález, D.M., Altman, D.G., Booth, A., Chan, A.W., Chang, S., Clifford, T., Dickersin, K., Egger, M., Gøtzsche, P.C., Grimshaw, J.M., Groves, T., Helfand, M., Higgins, J., Lasserson, T., Lau, J., Lohr, K., McGowan, J., Mulrow, C., Norton, M., Page, M., Sampson, M., Schünemann, H., Simera, I., Summerskill, W., Tetzlaff, J., Trikalinos, T.A., Tovey, D., Turner, L., and Whitlock, E., 2015. Preferred reporting items for systematic review and meta-analysis protocols (PRISMA-P) 2015 statement [Online]. Revista Espanola de Nutricion Humana y Dietetica. Asociacion Espanola de DietistasNutricionistas. Available from:

https://systematicreviewsjournal.biomedcentral.com/articles/10.1186/2046-4053-4-1 [Accessed 17 Apr 2021].

Naoum, S.G. and Egbu, C., 2016. Modern selection criteria for procurement methods in construction: A state-of-the-art literature review and a survey. International Journal of Managing Projects in Business, 9(2), pp. 309-336.

Ogbu, C.P. and Adindu, C.C., 2019. Direct risk factors and cost performance of road projects in developing countries: Contractors' perspective. Journal of Engineering, Design and Technology, 18 (2), pp. 326342 .

Polat, G., Okay, F. and Eray, E., 2014. Factors affecting cost overruns in micro-scaled construction companies. Procedia Engineering, 85, pp. 428-435.

Rosayuru, H.D.R.R. Waidyasekara, K.G.A.S. and Wijewickrama, M.K.C.S., 2018. Current practices of sustainable procurement in the Sri Lankan construction industry. In: 2018 Moratuwa Engineering Research Conference (MERCon). Institute of Electrical and Electronics Engineers Inc., pp. 144-149.

Saghatforoush, E., Hasim, S., Jaafar, M.S. and Kadir, M.R.A., 2009. constructability implementation among Malaysian building contractors. European Journal of Scientific Research, 29(4), pp. 518-532.

Samimpey, R. and Saghatforoush, E., 2020. A systematic review of prerequisites for constructability implementation in infrastructure projects. Civil Engineering Journal (Iran), 6(3), pp. 576-590.

Yang, Y.Q., Wang, S.Q., Dulaimi, M. and Low, S.P., 2003. A fuzzy quality function deployment system for buildable design decision-makings. Automation in Construction, 12, pp. 381-393.

Yustisia, H., 2014. The evaluation of constructability towards construction safety (case study: Kelok-9 bridge project, West Sumatra). Procedia Engineering. pp. 552-559.

Zolfagharian, S., Nourbakhsh, M., Mydin, S.H., Zin, R.M. and Irizarry, J., 2012. A conceptual method of constructability improvement. International Journal of Engineering and Technology, 4(4), pp. 456-459. 